\title{
Who Makes it Click? Understanding the Stakeholders in Agricultural Innovation Systems in Tripura State of India
}

\author{
Suchiradipta Bhattacharjee and R. Saravanan* \\ School of Social Sciences, College of Postgraduate Studies \\ Central Agricultural University (CAU) \\ Umiam (Barapani), Meghalaya, India
}

\begin{abstract}
The Agricultural Innovation System (AIS) is a network of organizations, enterprises and individuals that focuses on bringing new products, processes and forms of organization into economic use, together with the institutions and policies that affect their behaviour and performance. In the small North East Indian state of Tripura, System of Rice Intensification (SRI) has grown to develop into an innovation system where various stakeholders have come together to make the state self-sufficient in food grains. The present study was conducted to understand the characteristics of the leading stakeholders of the SRI innovation system in the state, their competence, relationship among each other and the enabling environment. Data was collected through a structured interview schedule and competence scale. Actor Linkage Matrix and descriptive statistical parameters were used to analyse data. The work of the administrative units at grass root levels to disseminate an agricultural technology is unprecedented. In addition, the contact between the research institutes and the farmers' needs to be improved and so does their exposure to other SRIpracticing parts of the country. The lessons learnt from the SRI innovation systems in Tripura, if applied to other similar crops and other similar parts of the country as well as in the developing world, would definitely prove to be a model for development and prosperity.
\end{abstract}

Keywords: Agricultural Innovation Systems (AIS), North East India, System of Rice Intensification (SRI), stakeholders, Tripura.

\section{INTRODUCTION}

The concept of innovation dates back to Rogers (1962) and that of "Innovation Systems" (IS) to Lundvall (1985). Innovation Systems is a new generation of development models that consist of a network of organizations, enterprises and individuals that focuses on bringing new products, new processes and new forms of organization into economic use, together with the institutions and policies that affect their behaviour and performance (World Bank, 2007). During the last twenty years, the literature on innovation has shifted from national (Lundvall, 1988) to regional (Lundvall, 1992) and local (Gottardi, 2000) dimensions. The concept of Innovation Systems stresses that the flow of information and technology among people, enterprise and institution is the key to an innovative process and the success of the system depends, to a large extent, on how the innovation system is build up and how it functions (Heimeriks, 2013). IS is a network of organizations of varying dynamics (Hall et al., 2006) and functions (Hekkert et al., 2007) with complex elements that change constantly over time, strongly influenced by the spatial pattern of their components (Hall \& Clark,

\footnotetext{
Corresponding author: saravananraj@hotmail.com
} 
2010). The concept of innovation system, with its distinctive functions, reveals the institutional factors that govern the relationship of elements and knowledge production in the system (Hall, 2006). IS has been identified as exogenous and endogenous - the former being initiated and controlled by outsiders and intended to improve the local livelihood and environment while the latter refers to the initiatives and innovation processes of the local people and includes the interwoven interactions of the technical, institutional, marketing or management innovation performances of the local people (Assefa et al., 2008).

\section{System of Rice Intensification in Asia: An overview}

Innovation in Agricultural Innovation Systems (AIS) is viewed in a social and economic sense and not purely as discovery and invention as the farmers or any other stakeholders are given equal importance in development of technology which is economically important and viable for them and so System of Rice Intensification (SRI) can be considered here. It is so because, as discussed earlier, SRI has been tried and tested by the farmers time and again and not one has followed all the principles to the book and still manages to get good economic returns. Comprehensive packages like Integrated Crop Management (ICM) developed by International Rice Research Institute (IRRI) have helped improve the rice production in developing countries like India, Indonesia and Philippines (Balasubramanian et al., 2011; Basu \& Leewis, 2012). But SRI, one such technology, was not initiated by any research institution but the continuous and tireless efforts for 34 years of a Father Henry de Laulanie in a church in Madagascar to increase the productivity of rice to help the poor farmers. SRI is an unusual innovation in several ways as it increases the productivity of land, labour, water and also increases the profit of the farmers at the same time and so, has proved itself worthy of the attention it is getting today (Uphoff, 2008). There is a growing debate within the international rice research community on efficacy and feasibility of SRI (Glover, 2011) but there are indications that SRI has spread more rapidly to different rice producing countries than ICM (CIIFAD, 2011), particularly in India and the Tripura state of the country has been a forerunner in this context. Prasad (2007) has observed that the innovation of SRI was very knowledge intensive and where technology precedes a full scientific understanding of why and how SRI works. But it has been best described by the ardent promoter of SRI Norman Uphoff, "SRI story is more than agriculture. It is equally about people, their needs, their capabilities, their limitations, their altruism and their creativity. In many respects, SRI is about potentials - socio-cultural and bio-physical - and about the expression of potentials within plant seeds, within soil systems and within human minds and spirits. And we can gain even more by working across sectors, institutions and statuses" (Radha \& Prasad, 2013).

The System of Rice Intensification (SRI), which was originally developed in the highlands of Madagascar, has evolved into a suite of flexible principles to be adapted to local conditions rather than a fixed technological package. Even the original SRI practices adopted by farmers in Madagascar have changed and continue to evolve (IRRI, 2013). The popularization of SRI in Madagascar was started nationally by Tefy Saina, an NGO established by Father de Laulanie and internationally by Cornell International Institute for Food, Agriculture and Development (CIIFAD). SRI has gained wide popularity in Asia and is now being practised in more than 30 countries though it has not been adopted on a wide scale in Africa or Madagascar itself (IRIN, 2012a). Bauman (2013) identified SRI as an "extremely successful participatory learning alliance that aims to develop a suite of management practices that farmers can choose from and adapt according to local conditions. It is a (grass-roots) movement, a way of doing R\&D in a participatory and inclusive manner, an experiential learning process. The success of this formula is testified to by the enthusiasm and result of tens of thousands of farmers and grass-roots practitioners all over the world". A 
wide range of yield increase has been observed in different Asian and African countries around the world with SRI (Table 1) (Verzola, Undated). Sudeep Karki from Norwegian University of Life Sciences and an SRI specialist from Nepal has compared SRI in agricultural development to a viral idea in social media - imposing its way from the ground to the top (IRIN, 2012b).

Table 1. Yield increase by SRI over conventional rice production method in some Asian and African countries

\begin{tabular}{cc}
\hline Country & Yield increase (\%) \\
\hline Gambia & 209 \\
Madagascar & 177 \\
Myanmar & 169 \\
Sri Lanka & 117 \\
Sierra Leone & 112 \\
Nepal & 102 \\
India & 100 \\
Philippines & 100 \\
Cambodia & 78 \\
Cuba & 72 \\
Indonesia & 48 \\
Bangladesh & 29 \\
China & 14 \\
\hline
\end{tabular}

According to FAO, China, India and Indonesia were the largest producers of rice in the world in 2010 while in 2012 India became the largest exporter of rice in the world (IRIN 2012b; The Indian Express, 2012). Asia produced and consumed 90\% of world's rice in 2010. Rice being the principal crop, SRI has been spreading fast in the Asian countries like China, Indonesia, Cambodia and Vietnam. In 2011, China had 700,000 ha, Indonesia had 100,000 ha and India had around five million ha under SRI. In Vietnam, within two years, the number of farmers practising SRI increased by three times. Spread of SRI in Cambodia was cited in 2010 as one of the 15 Asian success stories in the Millennium Development Goals endeavour. Even the methods of cultivation and the tools and techniques vary across countries in Asia. In Sri Lanka and Thailand, direct seeding has replaced transplanting of seedlings; In Nepal and Cambodia home-made weeders have been of great use in saving time; in Philippines and Myanmar SRI has been highly favoured in rain-fed and non-irrigated conditions (IRIN, 2012b). In Sri Lanka, the upward productivity shift, eco-friendliness of SRI by saving scarce water resources and reduction of production cost was found to create opportunities for creating food security among the poor (Somaratne, 2010). With 640 million undernourished and underfed people in Asia and the increasing global demand for rice (IRIN, 2010), SRI can be good enough solution, even if not a magical one.

The present study was conducted to understand the characteristics of primary stakeholders and their competence in SRI innovation systems in Tripura state of India and how these affect the strength of relationship among them. The study also tries to understand the support structures existing in the state that helped the dissemination of SRI in the state and helped increase the innovativeness of the stakeholders. 


\section{METHODOLOGY}

\section{Description of study area}

Located in the extreme south-west corner of North East region of India, Tripura state is a small sub-tropical state with geographical area of $10,492 \mathrm{sq} . \mathrm{km}$. It is surrounded by Bangladesh on three sides and Assam and Mizoram states of India on the other. Only 27\% of the total area of the state is cultivated of which a mere $4 \%$ is irrigated. Rice is the principal crop of the state (SRI-India, 2013) - both in terms of production and consumption and the livelihood security of a majority of the farmers depends on it. SRI has spread among the farmers of the state at a very fast rate. The number of SRI farmers increased from 1,000 to 70,000 in a mere two years (Uphoff, 2008). This has been possible with the tireless efforts of the stakeholders and enthusiasm of farmers and unique support from the village level decentralized administrative units, the Panchayati Raj Institutions. For the study, two out of four districts of the state were selected. West Tripura district, with all the agricultural research and extension organization headquarters and the state capital Agartala, has the highest area under rice and SRI (42\% of the total SRI area). Dhalai Tripura has been identified by Government of India as one of the country's 250 most backward districts and is currently receiving funds from Backward Regions Grant Fund (BRGF) Program. This district has the lowest area under rice and SRI (7\% of the total SRI area) in the state (DoA, 2013a). Rice being the principal crop of the state, it is cultivated in three seasons - Aush (April - June), Aman (July - November) and Boro (December - March). While in West Tripura rice is preferably cultivated in Aman and Boro, in Dhalai Tripura Aush and Aman are preferred due to scarcity of water in Boro.

\section{Data collection}

For the study, the extension organizations in the state working on SRI were selected by criterion and expert sampling for the study after discussion with key communicators from the Department of Agriculture and farmers. Selection of farmers were done by criterion sampling after consultation with key communicators from Department of Agriculture, Government of Tripura, Gram Pradhans (Village Panchayat heads), and contact farmers of the state department. For collection of data, six stakeholder organizations were studied from each district along with sixty six farmers. The total number of respondents interviewed for the study was 114. Data was collected with the help of a structured and pre-tested interview schedule prepared by consultation with experts from the Department of Agriculture and of extension. Each selected respondent was personally contacted and interviewed with the help of an interview schedule. 


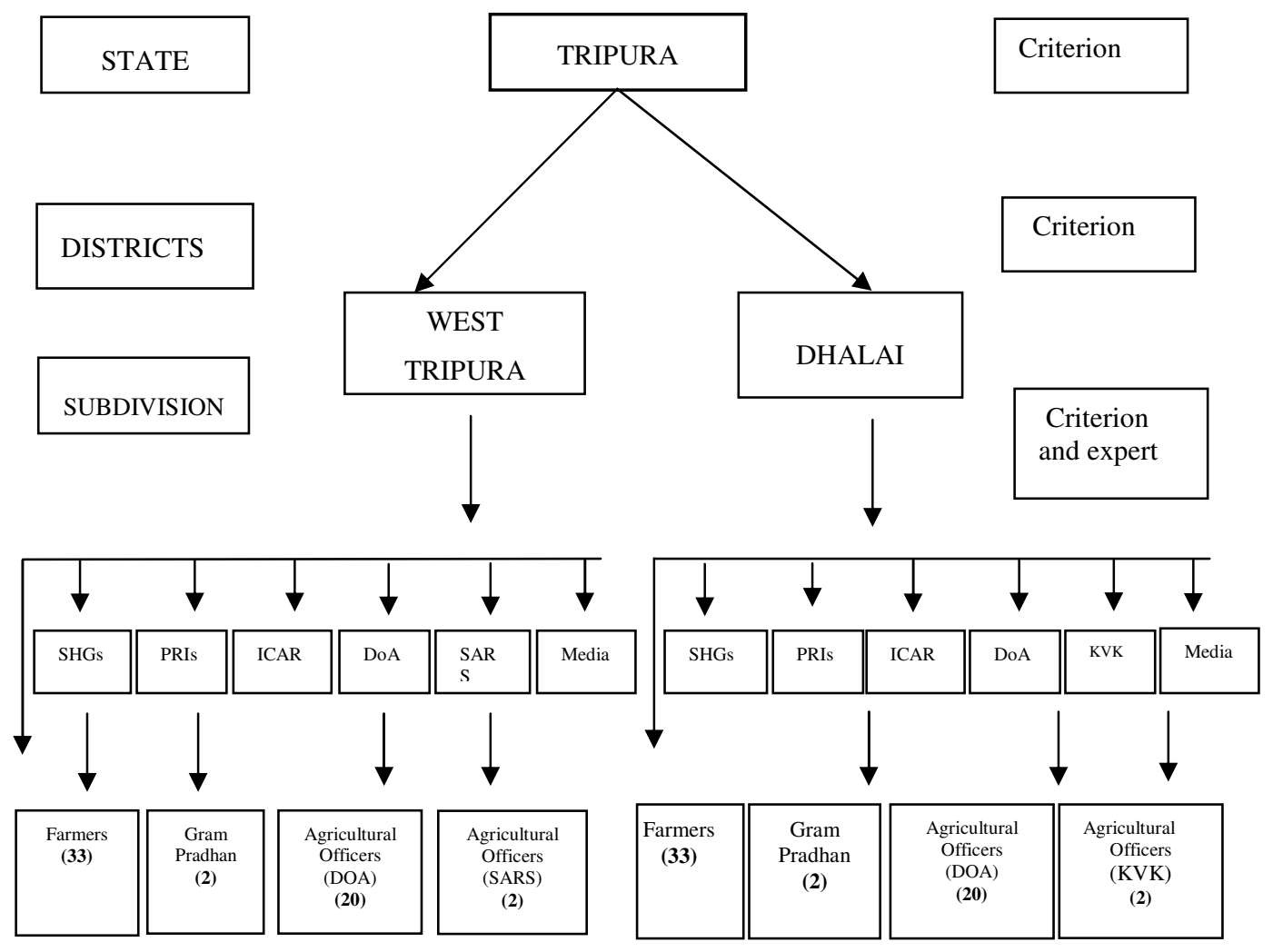

Fig. 1. Sampling plan for the study

\section{Data analysis}

The personal profile of the lead stakeholders of the state - farmers and the extension personnel from Department of Agriculture, Government of Tripura, State Agricultural Research Station and Krishi Vigyan Kendra were studied.

Competence was studied following the scale developed by Reddy (1990) and was operationally defined for the study as 'sufficiency or adequacy of the abilities or qualities possessed by a job incumbent which aid him or her, and ultimately the employing organization, in achieving the intended results'. In the scale developed by Reddy (1990), there were ten dimensions for measuring job competence, viz., technical knowledge, guidance skill, communication ability, adaptability, self development, creativity, empathy, mental agility, initiative and judgement. For the present study, the scale was modified according to the study situation and the dimensions studied for extension personnel were knowledge, guidance skill, communication ability, self development and mental agility. The scale contained 22 items in three point continuum of responses such as fully, to some extent and not at all and weightage given were 2, 1 and 0 respectively. The range of score that could be possible on the scale in case of each respondent was a maximum of 44 and minimum of zero. For studying the competence of the organizations, in addition to the competence of the employees, the target and achievement of the organization was also studied. In case of Department of Agriculture, sector offices were randomly selected from the district and their targets and achievement in SRI in the previous financial year 2011-2012 was studied. 
Competence of the farmers was studied with the scale of Reddy (1990) modified for the study. The dimensions studied were knowledge and skill in a three point continuum of responses - yes, sometimes and no weighing 2, 1 and 0 respectively. The scale contained 22 items and the maximum and minimum possible score that can be obtained by a respondent was 44 and 0 respectively.

The relationship between the stakeholders was studied using Actor Linkage Matrix (Biggs \& Matsaert, 2004). The actor linkage matrix is used to identify all the actors and shows the links between the major actors in the innovation system. The cells in the matrix represent the strength of relationships between the actors and helps in pinpointing particularly significant links among actors in the innovation system. Information about the linkage strength of the stakeholders among themselves was obtained from focused group discussion and interview schedule.

Chi Square Test was used to study the association between personal characteristics of the farmers with competence and their relationship strength with other stakeholders in the innovation systems.

To study the enabling environment in the state for innovation and increasing the innovation capacity of the stakeholders of the SRI innovation systems, the policy and support structures existing in the state were studied. For the present study, the policy and support structures were studied from both primary and secondary data.

\section{RESULTS AND DISCUSSION}

\section{Stakeholders of Agricultural Innovation Systems in SRI in Tripura state}

The stakeholders identified in the Agricultural innovation systems in SRI in Tripura state are listed in Table 2 and discussed below.

Table 2. Stakeholders in the SRI innovation systems in Tripura

\begin{tabular}{|c|c|c|}
\hline Public & Farmers and their collectives & Media \\
\hline $\begin{array}{l}\text { - Ministry of Agriculture, Government of India } \\
\text { (MoA, GoI) } \\
\text { - Directorate of Rice Research, Hyderabad (DRR) } \\
\text { - Indian Council of Agricultural Research - } \\
\text { Research Complex for North East Hill Region, } \\
\text { Tripura Centre (ICAR-RC for NEH Region, Tripura } \\
\text { Centre) } \\
\text { - Department of Agriculture, Government of } \\
\text { Tripura (40) } \\
\text { - State Agricultural Research Station, DoA, GoT } \\
\text { (2) } \\
\text { - Panchayati Raj Institutions (4) } \\
\text { - Farm Science Centre/ Krishi Vigyan Kendra } \\
\text { (KVK) (2) }\end{array}$ & $\begin{array}{l}\text { - Farmers (60) } \\
\text { - Self Help Groups (SHGs) } \\
\text { (6) }\end{array}$ & $\begin{array}{l}\text { - Local newspapers (Daily } \\
\text { Desher Katha and Dainik } \\
\text { Sambad) } \\
\text { - Radio (Akashvani Agartala) } \\
\text { - Local and national television } \\
\text { (Doordarshan Kendra, } \\
\text { Agartala; e-TV Bangla; } \\
\text { Bangladesh Television) }\end{array}$ \\
\hline
\end{tabular}


The public organizations, farmers and media have been the main stakeholders of SRI innovation systems in the state. Department of Agriculture, Government of Tripura (DoA, GoT) has been the lead actor in the system with technical support from Directorate of Rice Research (DRR), Andhra Pradesh, India and financial and policy support from Ministry of Agriculture, Government of India. DoA, GoT looks after the agricultural aspects of the state. Agriculture being a state subject, all the developments and reforms in the sector are being taken care of by the Department headed by the Minister of Agriculture of the state of Tripura.

DRR, established by Indian Council of Agricultural Research (ICAR) is an apex body in rice research in the country and mainly coordinates multi-location testing at national level to identify appropriate varietal and management technologies for all the rice ecosystems (DRR, 2013).

State Agricultural Research Station (SARS), Government of Tripura, has mostly been involved in research and providing technical support to the extension personnel. In view of its significant contribution towards the rice research and development it has become a voluntary centre of All India Coordinated Rice Improvement Programme. (DoA, 2013b).

The Indian Council of Agricultural Research (ICAR) is an autonomous organisation under the Department of Agricultural Research and Education (DARE), Ministry of Agriculture, Government of India. The Council is the apex body for co-ordinating, guiding and managing research and education in agriculture including horticulture, fisheries and animal sciences in the entire country. The ICAR Research Complex for North East Hill Region, Tripura Centre was established in the year 1975 with a mandate to provide adequate research base in agriculture, horticulture, fisheries and animal husbandry for collection and preservation of cultivated or wild germplasm in crops, animals and fisheries for their subsequent utilization in improvement program and dissemination to the farming community (ICAR-RC for NEH Region, Tripura Centre, 2013).

The Panchayati Raj system in Tripura is guided by the Tripura Panchayats Act, 1983 and after the 73rd Amendment Act was brought in, the government enacted the Tripura Panchayat Act, 1993. It provided a three-tier Panchayati Raj structure with Gram Panchayat at the village, Panchayat Samiti at the block and Zilla Parishad at the district levels. Gram Panchayats are constituted below the block level and consist of a number of constituencies called Wards. The Panchayati Raj Institutions (PRIs) are mandated with the responsibility for preparation of plans for economic development and social justice, and its agency functions relate to the implementation of schemes for economic development and social justice (Tripurainfo, 2013).

Farm Science Centre, Dhalai under the host organization Directorate of Agriculture, Government of Tripura was established in 2011 in the district. The Farm Science Centre gets its human resource from the Department of Agriculture whereas technical and financial support from ICAR-RC for NEH Region, Meghalaya, India.

Tripura's economy is mostly dependent on agriculture and so the farmers play a major role in agricultural innovation and as such, farmers have been the most important stakeholders of SRI in the state. Even though they have been basically receivers of the technology, but their enthusiasm and ready acceptance has made SRI a big success in the state. The farmers' collectives are the Self Help Groups formed by the Department under Registered Seed 
Growers Program. These groups produce rice seeds which the Government buys from them and sell to the SRI farmers at subsidised rates.

Media in Tripura has an active role in agricultural information dissemination. The two major newspapers of the state have a dedicated page on a weekday (Daily Desher Katha on Saturday and Dainik Sambad on Wednesday) on agriculture whereas electronic media like TV and Radio have also been playing an important role with their agricultural program. While Doordarshan Kendra (Agartala) telecasts agricultural program ('Krishi Darshan') Monday to Friday from 6 to $6: 30 \mathrm{pm}$, Akashvani Agartala broadcasts their programs 'Chasher Katha' (Farmers' story) everyday from 6:45 to 7 am and 12:55 to 1:15 pm and 'Baro Grihastir Ashar' (Rural Family Program) daily from 6:30 to 7 pm.

\section{Personal profile of extension personnel and farmers}

Personal profile of the extension personnel studied was age, sex and educational qualification. Majority $(58.33 \%)$ of the extension personnel were found to be middle aged (35-50 years) followed by old ( $>50$ years) $(31.25 \%$ ) due to low rate of employment in the state. Since the male personnel were preferred for field visits and women personnel were mostly involved with the paper works in the office, the former $(91.67 \%)$ were mostly taken up as respondents for the study to get a better understanding of the lead actors of the SRI innovation systems in the state. The Agriculture Officers $(58.33 \%)$ were specialised in agriculture at graduation level which was the minimum qualification required for the job while 41.66 per cent of the Village Level Workers (VLWs) were matriculation pass, which was the minimum qualification for the job.

The farmers studied belonged to mostly old age group (above 50 years) and middle age group (35-50 years) due to their years of experience in farming and were all male farmers because of the societal norms where men are the owner of the land. All farmers had basic education till middle school (Class VIII). Fifty per cent of the farmers were marginal land holders (owns less than 1 ha area) and $60 \%$ of the total respondents belonged to middle income group (INR 33, 751 - INR 1,44,000). Due to multiple cropping season and increasing area under irrigation in the state, cropping intensity (percentage of area cropped annually) and irrigation intensity (percentage of area irrigated annually) was pretty high in the state. A majority of the farmers $(33.33 \%)$ irrigated their fields through canals followed by shallow motor (26.66), Lift Irrigation (6.67) and switch gate (6.67). But some of the farmers (26.66\%) had no irrigation source at all and used rain water to irrigate the fields during Aman and Aush and generally kept their lands fallow during Boro or winter season. While 86.67 per cent had medium cropping intensity (210.44-182.86 per cent), 58.33 per cent had high irrigation intensity (177.51-300). The farmers mostly preferred to stay inside the village and their main sources of information related to SRI were personal cosmopolite (extension personnel) $(26.67 \%)$ and personal localite (other farmers) $(61.67 \%)$.

\section{Competence of stakeholders}

Competence of stakeholder organizations decides their innovativeness to a good extent. In order to study the competence of the stakeholders of SRI in Tripura, the two leading stakeholders - Department of Agriculture (DoA) and farmers were studied. The competence of DoA was studied on the basis of the target and achievement of area covered under SRI of the sector offices in the previous year and individual competence of the employees which adds to the competence of the organization. All the sector offices studied for the purpose 
were able to fulfil their targets of area under SRI in the previous year in both hybrid and High Yielding Variety (HYV) rice cultivated through SRI method.

Table 3. Association between Competence of farmers and their personal characteristics

\begin{tabular}{|c|c|c|c|c|c|}
\hline $\begin{array}{c}\text { Dependent } \\
\text { variable }\end{array}$ & $\begin{array}{c}\text { Independent } \\
\text { variable }\end{array}$ & $\begin{array}{c}\text { Chi Square } \\
\text { Test value } \\
\text { (Dhalai } \\
\text { district) }\end{array}$ & Comment* & $\begin{array}{c}\text { Chi Square } \\
\text { Test value } \\
\text { (West } \\
\text { district) }\end{array}$ & Comment* \\
\hline \multirow{11}{*}{ Competence } & Age & 0.905 & Not significant & 0.003 & Significant \\
\hline & Education & 0.000 & Significant & 0.001 & Significant \\
\hline & Social Category & 0.007 & Significant & 0.202 & Not significant \\
\hline & Farming experience & 0.003 & Significant & 0.000 & Significant \\
\hline & Farm size & 0.000 & Significant & 0.000 & Significant \\
\hline & Irrigation type & 0.021 & Significant & 0.028 & Significant \\
\hline & Cropping intensity & 0.000 & Significant & 0.363 & Not significant \\
\hline & Irrigation intensity & 0.497 & Not significant & 0.000 & Significant \\
\hline & Occupation & 0.000 & Significant & 0.028 & Significant \\
\hline & Annual income & 0.122 & Not significant & 0.011 & Significant \\
\hline & Cosmopoliteness & 0.000 & Significant & 0.025 & Significant \\
\hline
\end{tabular}

While the Agricultural Extension Officers (AEOs) mostly showed medium (50\%) competence followed by high (45.83\%) and low (4.16\%), the Village level Workers (VLWs) and Krishak Bandhu (KB) (the village youth identified by local administrative unit to assist the VLW in their work and paid by the Department of agriculture on a contractual basis) had medium competence followed by low competence. Majority of farmers studied had medium $(41.67 \%)$ competence followed by low (30\%) and high $(28.33 \%)$. Education, farming experience, farm size, irrigation source, occupation and cosmopoliteness were found to be significantly related to competence of the farmers in the state by Chi Square Test for association (Table 3). The more educated farmers were better in understanding and adopting the principles of SRI, thus increasing their competence. With experience also, the farmers learn what is more suitable to their situation and gain better understanding of the practical aspect of the principles of SRI. The farmers with larger farm size were dependent on SRI for their livelihood and so were more keen on following the principles of SRI by book and also had knowledge on recent developments related to the technology. Since farmers with a steady irrigation source were more inclined to take up SRI, they were found to have more interest and hence more knowledge on SRI. Knowing the principles of SRI and following them properly is important to increase the yield through SRI and for that, the farmers had to keep in constant touch with extension personnel and media because the recent technological knowledge was not so prevalent among their fellow farmers and so Cosmopoliteness was significantly related with the competence of the farmers.

\section{Actor Linkage Matrix}

The actor linkage matrix of the actors in SRI innovation systems in two selected districts of Tripura revealed DoA as the lead link. The department has been sharing a fair relationship with the MoA which is mainly guided by policy implementation. While the department personnel had a poor relation with DRR in West Tripura, in Dhalai they had a fair relationship with the organization. Generally the technical aspects were dealt by DRR and the extension functionaries of the department have been receiving help related to these aspects from the organization. Similarly, with ICAR-RC for NEH Region, Tripura Centre, 
the department had a poor relation in West due to non-involvement of the former in SRI in recent times. ICAR-RC for NEH Region, Tripura Centre is more involved in Integrated Crop Management (ICM) and varietal research and breeding programs of various plants and livestock, hence not much involved in SRI. In Dhalai, ICAR-RC for NEH Region, Tripura Centre had establishes a KVK and through it, the relationship of DoA was fair with ICAR$\mathrm{RC}$ for NEH Region, Tripura Centre. While intra-organizational linkage is very efficient in the department, it also shares a good relationship with the research wing (SARS). SARS looks after the R\&D aspect of SRI and the extension functionaries receive regular updates from SARS to make their working more efficient. Department had a fair relationship with the PRIs as through them they received the list of beneficiaries of SRI every cropping season. It helped the department in fulfilling its targets and the expansion of SRI in farmers' field also becomes easier. The department had a good relationship with the SHGs in the West but fair in Dhalai. This is so because the numbers of SHGs in West were much higher than in Dhalai. The DoA has been maintaining a very good relationship with the SRI farmers through the extension functionaries and has been taking care of their information and resource needs. The DoA has a poor relationship with the media as the media does its work independently and the DoA has its own extension methods to create awareness.

Same as the DoA, SARS has a good relation with the MoA due to policy matters. Being a R\&D organization, it has a fair relationship with DRR but SRI being more of a social innovation than technological innovation, there is not much to keep a tab on. The intraorganizational communication or linkage is very good which makes the work of the department flexible and compartmentalized for efficient functioning. SARS also has very good relation with the PRIs providing them with technical details of SRI and keep a tab on the recent developments. SARS has a fair relation with media being in touch with them for broadcasting program on SRI. PRIs are administrative units at local grass-root levels and so are important parts of the villages. The department depends a great deal on the PRIs for implementation of any policy or program as they are closest to the rural people. PRIs share pretty good relationship with the DoA as it selects the beneficiaries for different project implementation. Farmers and SHGs, being part of the rural infrastructure, are closely related to the PRIs for any assistance. These administrative units do not have any link with the media.

The farmers received strong information support from the department, other farmers and the PRIs and medium support from the SHGs. The farmers had poor relationship with ICAR-RC for NEH Region, Tripura Centre and SARS. In the village, the VLWs are considered as the most credible source of information on SRI and the farmers depended on them for all their information needs. Other than that, they also receive assistance from the Agricultural Extension Officers and the Krishak Bandhu. Since the Panchayat selects beneficiaries for SRI, the farmers stay in close contact with the Panchayat for any assistance and also for other necessities like subsidised machineries for intercultural operations, pump sets for irrigation, etc. Other than that, every 3-4 days in a week the farmers sit together in informal gatherings in the villages and exchange information among them. Farmers of Dhalai shared a good relation with the KVK as the KVK personnel visited the farmers' field once or twice a week and keep in touch with them. But farmers of West Tripura district did not have any direct link with the SARS which was more closely involved with the extension personnel.

Since the study was conducted in Tripura and due to limitation of resources, Ministry of Agriculture, GoI, New Delhi and Directorate of Rice Research, Hyderabad, Andhra Pradesh could not be contacted as both the stakeholders are located outside the state. Moreover, there was no specific official identified during Focussed group discussion from either organization 
who were responsible for all matters related to SRI in Tripura. ICAR-RC for NEH Region, Tripura Centre officials, when contacted, said they were not working on SRI anymore and so could not provide any information. Media is working on their own for public interest and even though through extensive publication and broadcasts has become a stakeholder but do not have any links as such with any of the other stakeholders in the state.

Table 4. Relationship between actors in West Tripura district

\begin{tabular}{|c|c|c|c|c|c|c|c|c|c|}
\hline & MoA & DRR & $\begin{array}{c}\text { ICAR-RC } \\
\text { for NEH } \\
\text { Region, } \\
\text { Tripura } \\
\text { Centre }\end{array}$ & DoA & SARS & PRIs & SHGs & Farmers & Media \\
\hline MoA & $\mathrm{X}$ & & & & & & & & \\
\hline DRR & & $\mathrm{X}$ & & & & & & & \\
\hline $\begin{array}{l}\text { ICAR-RC } \\
\text { for NEH } \\
\text { Region, } \\
\text { Tripura } \\
\text { Centre }\end{array}$ & & & $\mathrm{X}$ & & & & & & \\
\hline DoA & 1.83 & 0.29 & 0.86 & $X$ & 3.1 & 1.62 & 2.73 & 4 & 0.29 \\
\hline SARS & 4 & 2 & 0 & 4 & $X$ & 3.5 & 3 & 4 & 2 \\
\hline PRI & 0 & 0 & 0 & 4 & 4 & $X$ & 2 & 4 & 0 \\
\hline SHGs & 0 & 0 & 0.1 & 4 & 2 & 4 & $X$ & 4 & 0 \\
\hline Farmers & 0 & 0 & 0.1 & 4 & 0.5 & 4 & 2 & $X$ & 0 \\
\hline Media & & & & & & & & & X \\
\hline
\end{tabular}

(0=no relation; 0-1=poor; 1.1-2=fair; 2.1-3=good; 3.1-4=very good; blank cells=don't know)

Table 5. Relationship between actors in Dhalai Tripura district

\begin{tabular}{|c|c|c|c|c|c|c|c|c|c|}
\hline & MoA & DRR & $\begin{array}{c}\text { ICAR-RC for } \\
\text { NEH Region, } \\
\text { Tripura } \\
\text { Centre }\end{array}$ & DoA & KVK & PRIs & SHGs & Farmers & Media \\
\hline MoA & $X$ & & & & & & & & \\
\hline DRR & & $X$ & & & & & & & \\
\hline $\begin{array}{l}\text { ICAR-RC } \\
\text { for NEH } \\
\text { Region, } \\
\text { Tripura } \\
\text { Centre }\end{array}$ & & & $\mathrm{X}$ & & & & & & \\
\hline DoA & 1.8 & 0 & 1.5 & $X$ & 4 & 4 & 1.1 & 4 & 0 \\
\hline KVK & 0 & 1.5 & 4 & 4 & $\mathrm{X}$ & 4 & 1 & 4 & 0 \\
\hline PRI & 0 & 0 & 0 & 4 & 4 & $X$ & 4 & 4 & 0 \\
\hline SHGs & 0 & 0 & 1 & 4 & 1 & 4 & $\mathrm{X}$ & 4 & 0 \\
\hline Farmers & 0 & 0 & 1 & 3.4 & 4 & 4 & 4 & $X$ & 0 \\
\hline Media & & & & & & & & & $\mathrm{X}$ \\
\hline
\end{tabular}

(0=no relation; 0-1=poor; 1.1-2=fair; 2.1-3=good; 3.1-4=very good; blank cells=don't know)

(MoA=Ministry of Agriculture, Government of India; DRR=Directorate of Rice Research; ICAR-RC for NEH Region, Tripura Centre=Indian Council of Agricultural Research - Research Complex for North East Hill Region; DoA=Department of Agriculture, Government of Tripura; KVK=Krishi Vigyan Kendra; PRIs=Panchayati Raj Institutions; SHGs=Self Help Groups) 
Table 6. Association between relationship strength of farmers with other stakeholders and their personal characteristics

\begin{tabular}{|c|c|c|c|c|c|}
\hline $\begin{array}{c}\text { Dependent } \\
\text { variable }\end{array}$ & $\begin{array}{c}\text { Independent } \\
\text { variable }\end{array}$ & $\begin{array}{c}\text { Chi } \\
\text { Square } \\
\text { Test } \\
\text { value } \\
\text { (Dhalai } \\
\text { district) } \\
\end{array}$ & Comment* & $\begin{array}{c}\text { Chi Square } \\
\text { Test value } \\
\text { (West } \\
\text { district) }\end{array}$ & Comment* \\
\hline \multirow{11}{*}{$\begin{array}{l}\text { Relationship } \\
\text { strength }\end{array}$} & Age & 0.905 & Not significant & 0.741 & $\begin{array}{c}\text { Not } \\
\text { significant }\end{array}$ \\
\hline & Education & 0.000 & Significant & 0.001 & Significant \\
\hline & Social Category & 0.007 & Significant & 0.202 & $\begin{array}{c}\text { Not } \\
\text { significant }\end{array}$ \\
\hline & Farming experience & 0.003 & Significant & 0.000 & Significant \\
\hline & Farm size & 0.000 & Significant & 0.000 & Significant \\
\hline & Irrigation type & 0.021 & Significant & 0.028 & Significant \\
\hline & Cropping intensity & 0.000 & Significant & 0.363 & $\begin{array}{c}\text { Not } \\
\text { significant }\end{array}$ \\
\hline & Irrigation intensity & 0.497 & Not significant & 0.000 & Significant \\
\hline & Occupation & 0.000 & Significant & 0.028 & Significant \\
\hline & Annual income & 0.122 & Not significant & 0.011 & Significant \\
\hline & Cosmopoliteness & 0.000 & Significant & 0.025 & Significant \\
\hline
\end{tabular}

(*Significant at $5 \%$ level of significance)

Education, farming experience, farm size, irrigation source/type, occupation and cosmopoliteness of farmers were found to have significant relationship with their strength of relationship with other stakeholders (Table 6). The higher educated farmers were found to visit the VLW office and Panchayat Office at least once a week to collect information regarding SRI and other aspects of farming as stated by them during data collection and nearly every day they have been found to meet up with other farmers in the evening and discuss farming related queries. Farmers with regular water source were more inclined to SRI, thus depending on other farmers, extension personnel and media for information. Naturally, the cosmopoliteness was significantly related to strength of relationship as the farmers had more inclination towards staying informed through connections with different sources regarding new technologies and Government schemes and subsidies aimed towards farmers. Most of the respondents $(68.34 \%)$ were solely dependent on agriculture and hence were more eager to get information regarding SRI by maintaining a good relation with extension personnel and fellow SRI farmers.

\section{Policy and support structure}

Policies and support structures that have been existing in the state since introduction of SRI gave the farmers the courage to take up SRI as they thought it was a huge risk at the beginning. Moreover, the price of rice being low in the state and rice cultivation becoming less profitable by the day, SRI has been increasing the profit and the support from the Govt. has been reducing the input cost. Major support has been provided through Macro Management in Agriculture (MMA), Rashtriya Krishi Vikas Yojana (RKVY) and recently introduced National Food Security Mission (NFSM) and Perspective Plan of the state government has given the target to achieve. During the initial stages of SRI in the state, the fund for research and promotion was received from MMA till RKVY funds were allocated for the purpose in the year 2008-2009. A part of the RKVY fund in Tripura is directed to assist the marginal and small SRI farmers in Tripura. A total of INR 3916 is given to each beneficiary farmer who opted for SRI cultivation both in cash and kind under the scheme. The NFSM fund is being utilized for SRI since 2011-12. The assistance provided under 
NFSM is INR 7000 per hectare for one unit SRI farm (1 unit=10 ha). The beneficiaries in the state are separate for RKVY and NFSM who are chosen by the Gram Panchayat. Assistance under Perspective Plan was to be given at reduced level for critical inputs like chemical fertilizers, bio-fertilizers, etc. amounting to INR 1650 per ha (Rupees one thousand six hundred and fifty only) against the existing level of INR 3916 per ha (DoA, 2012).

\section{CONCLUSION}

SRI in Tripura has been a mass movement that brought about not only agricultural but social change in the rural areas. This has been made possible by the constant interaction of research, extension and farmers and by making the system conductive by proper policy implementation. Department of Agriculture has played a lead role in the state for introduction and dissemination of SRI technology and also has maintained a good relationship with other stakeholders in the Agricultural Innovation Systems. The farmers also had a strong relationship among themselves which further made the job of dissemination of SRI faster and more efficient. Help was extended from the Panchayati Raj Institutions (PRIs), the administrative units at the grass-root level which was also a reason for the flair of the AIS in SRI in Tripura. Moreover, proper relationship at the proper place and time and with a conductive environment has played an important role to increase the competence of stakeholders. In the developing world where hunger, poverty and malnutrition are deadly threats, the innovation systems can be very useful. Following the example and improving along the way along with others can definitely prove to pave a way out of poverty and unemployment in a sustainable manner and that is the need of the hour.

\section{REFERENCES}

Assefa, A., Waters-Bayer, A., Fincham, R. and Mudahara, M. (2008). Comparison of frameworks for studying grassroots innovation: Agricultural Innovation Systems (AIS) and Agricultural Knowledge and Information Systems (AKIS). http://www.cgiarilac.org/files/Assefa_Comparison.pdf. (Accessed on 08.11.2012).

Balasubramanian, V., Rajendran, R., Anbumani, S., Stalin, P., Thiagarajan, T.M., Castro, E., Chandrasekaran, B., Las, I. (2011). Integrated Crop Management (ICM) for sustaining irrigated rice yields and farmers' income in Asia.

http://www.wassan.org./sri/documents/Lead/Lead10.mht. (Accessed on 03.07.2013).

Basu, S. and Leeuwis, C. (2012). Understanding the rapid spread of System of Rice Intensification (SRI) in Andhra Pradesh: Exploring the building of support networks and media representation. Agricultural Systems, Vol 111, pp 34-44.

Bauman, B. (2013). SRI: Why the animosity?

http://irri.org/index.php?option=com_k2\&view=item\&id=12538:sri-why-theanimosity?\&lang=en (Accessed on 04.07.2013).

Biggs, S and Matsaert, H. (2004). Strengthening poverty reduction programmes using an actor-oriented approach: Examples from natural resources innovation systems. AgREN Network Paper No. 134.

http://www.citeseerx.ist.psu.edu/viewdoc/download?doi=10.1.1.198.4069\&rep=rep1\&type= pdf. (Accessed on 15th January, 2013). 
CIIFAD. (2011). The System of Rice Intensification (SRI): India SRI Activities. Ithaca. Retrieved from http://ciifad.cornell.edu/sri/countries/india/indiaarchives.html (Accessed on 21/11/2012).

DoA (Department of Agriculture, Government of Tripura). (2012). Krishi Krishak o Tripura: 1972- 2012 (Bengali). Report. Branch of Agricultural Extension, Department of Agriculture, Govt. of Tripura.

DoA (Department of Agriculture, Government of Tripura). (2013a). Area, Production and Yield of Rice under SRI in Tripura - 2009-2013.

DoA (Department of Agriculture, Government of Tripura). (2013b). Department of Agriculture: Research. http://agri.tripura.gov.in/research.htm. (Accessed on 01.05.2013).

Directorate of Rice Research. (2013). DRR - About Us.

http://www.drricar.org/index.php?option=com_content\&view=article\&id=14\&Itemid=1\&lan $\mathrm{g}=\mathrm{en}$. (Accessed on 18.05.2013).

Freeman, C. (1995). The National System of Innovation in historical perspective. Cambridge Journal of Economics. 19, 5 - 24.

Glover, D. (2011). The system of rice intensification: Time for an empirical turn. NJAS Wageningen Journal of Life Sciences, 57, 217 - 224.

Gottardi, G. (2000). Innovation and the creation of knowledge in Italian industrial districts: A system model. In: F. Belussi \& G. Gottardi (eds) Evolutionary Patterns of Local Industrial System, Aldershot, Ashgate Publishing Ltd.

Hall, A. (2006). Public private sector partnerships in an agricultural system of innovation: Concepts and challenges. Working Paper Series 2006-002. United Nations University Maastricht Economic and social Research and training centre on Innovation and Technology (UNU-MERIT), Netherlands.

Hall, A. and Clark, N. (2010). What do complex adaptive systems look like and what are the implications for innovation policy? Journal of International Development 22, 308 - 324.

Hall, A., Mytelka, L. and Oyeyinka, B. (2006). Concepts and guidelines for diagnostic assessment of agricultural innovation capacity. Working Paper Series 2006-017. United Nations University - Maastricht Economic and social Research and training centre on Innovation and Technology (UNU-MERIT), Netherlands.

Heimeriks, G. (2013). Measuring and modelling innovation Lesson 6: Innovation Systems. http://heimeriks.net/measuring-and-modelling-innovation/mmi-lesson-6-innovationsystems/. (Accessed on 18.01.2013).

Hekkert, M.P., Suurs, R.A.A., Negro, S.O., Kuhlmann, S. and Smits, R.E.H.M. (2007). Functions of Innovation Systems: A new approach for analysing technological change. Technological Forecasting and Social Change, 74, 413 - 432.

ICAR, Tripura Centre. (2013). Organization. http://tripuraicar.nic.in. Accessed on $18^{\text {th }}$ May, 2013. 
IRIN, (2010). Asia: Key facts about rice. http://www.irinnews.org/report/91012/asia-keyfacts-about-rice (Accessed on 05.07.2013).

IRIN (2012a). Madagascar: The "less is more" philosophy of rice production. http://www.irinnews.org/report/94764/madagascar-the-less-is-more-philosophy-of-riceproduction (Accessed on 14.07.2013).

IRIN, (2012b). Analysis: Why rice intensification matters in Asia. http://www.irinnews.org/report/95342/analysis-why-rice-intensification-matters-in-asia (Accessed on 05.07.2013).

IRRI (International Rice Research Institute), (2013). Origins and definitions of SRI. http://irri.org/index.php?option=com_k2\&view=item\&layout=item\&id=11951\&Itemid=100 903\&lang=en (Accessed on 04.07.2013).

Lundvall, B.A. (1985). Product innovation and user-producer interaction. Alborg University Press. http://vbn.aau.dk/files/7556474/user-producer.pdf. (Accessed on 20th May, 2013).

Lundvall, B.A. (1988). Innovation as an interactive process: From user-producer interaction to the National Innovation Systems. In: Dosi, G., Freeman, C., Nelson, R.R., Silverberg, G. and Soete, L.,(Eds.). Technology and economic theory, Pinter Publishers, London.

Lundvall, B.A. (1992). National systems of innovation: Towards a theory of innovationand interactive learning. Pinter Publishers, London.

Prasad, C.S, (2007). Rethinking innovation and development: Insights from the System of Rice Intensification (SRI) in India. The Public Sector Innovation Journal 12(2), article 3.

Radha, T.M., Prasad, K.V.S, (2013). SRI: A scaling up success. LEISA India, 15(1), 4.

Reddy, N. (1990). Job competence and job performance of Agricultural Officers in Training and Visit system of Andhra Pradesh. Ph.D thesis. Department of Agricultural Extension, University of Agricultural Sciences, Bangalore.

Rogers, E.M. (1962). Diffusion of Innovations. Glencoe, Free Press. pp-11.

Somaratne, W. G. (2010). The System of Rice Intensification (SRI) and food security among the poor: opportunities and constraints. Retrieved from http://publications.iwmi.org/pdf/H042897.pdf (Accessed on 24.07.2013).

Sinha, P.R.R. and Kolte, N.V. (1974). Adult education in relation to agricultural development: An evaluative study of a development block in Andhra Pradesh. National Institute of Rural Development, Hyderabad.

SRI-India. (2013). SRI factsheet - Tripura. Retrieved from http://www.sriindia.net/html/aboutsri_tripura.html. (Accessed on 23.01. 2013).

The Indian Express, (2012). India is world's largest rice exporter: USDA. http://www.indianexpress.com/news/india-is-worlds-largest-rice-exporter-usda/1023491/ (Accessed on 05.07.2013). 
Uphoff, N. (2008). The System of Rice Intensification (SRI) as a System of Agricultural Innovation. Retrieved from http://repository.ipb.ac.id/handle/123456789/43778. (Accessed on 04.01.2013).

Verzola, R.S. (Undated). System of Rice Intensification (SRI): Practices and Results in the Philippines. http://ciifad.cornell.edu/sri/countries/philippines/philverzcf.pdf (Accessed on 04.07.2013).

World Bank. (2007). The Innovation Systems concept: a framework. In: Enhancing Agricultural Innovation: How to go Beyond the Strengthening of Research Systems. World Bank. Washington DC. 